\title{
Feminists Destroy Everything
}

After watching the same television ad several times, I concluded that it was the most discriminatory thing I had ever seen, even worse than Donald Sterling's disgraceful comments about Blacks. It was an ATT ad of a young saleswoman pitching four older executive women, each of whom had a comment, while a wimpy dumb executive man at the periphery and back of the group looks stupid, says nothing and then postures himself in imitation of the women's gestures. This mockery of men is outrageous and much more elaborate than the $\mathrm{N}$ word or Sterling's private mutterings. This thing is being shown many times daily for months. Worst, the message conveyed to boys is harmful and hateful. Those responsible should be expelled from all advertising forever just as Sterling was from the National Basketball Association.

As I reflected on this ad, several points about feminism seemed evident:

1. Feminists are frauds when they themselves use against men the very discrimination about which they complain has been used against women (The same applies to all victimhood wackos)

2. Feminists destroy the family when they hit on married men. In my youth, young women respected married women by never getting involved with a married man: "He belongs to her!" was the overt rule understood by all and almost universally followed. That a man is married is no longer respected as part of the female rights of his wife.

3. Feminists have adopted male sexuality incompetently--as one hears young women complain of "rape" after placing themselves in flagrant copulation expected situations but then feel guilty needing, once sober, to deny consent and reject readily seen consequences not cared about when high or enjoying the excitement of a copulation expected situation. In a masturbatory culture with sexuality reduced to simple squirting and sliming any way every way, feminists cannot complain when they place themselves where and when it is expected and can easily happen.

4. Feminists have destroyed the prime dictionary meaning of female as "designating the sex that produces ova and bears offspring" (For male, it is "designating the sex that fertilizes the ovum and begets offspring."). Thus, the planetary and natural functioning of humans have been destroyed by feminists.

5. Feminists openly demean and dis-empower males beginning in grade schools as the special needs of boys (because of their innate higher activity levels) are punished rather than converted into intellectual pursuits.

6. Feminists consider "family" to be a problem rather than the

Opinion
Volume 6 Issue 1 - 2016
Dr. Samuel A Nigro M.D*
Retired, Assistant Clinical Professor Psychiatry, Case Western
Reserve University School of Medicine, USA
*Corresponding author: Dr. Samuel A Nigro M.D, Retired,
Assistant Clinical Professor Psychiatry, Case Western Reserve
University School of Medicine, 2517 Guilford Road, Cleveland
Heights, Ohio 44118, USA, Tel: 216 932-0575; Email:
sam@docnigro.com
Received: November 11, 2015 | Published: June 02, 2016

natural traditional solution to incivility and lack of culture.

7. Feminists want the natural traditional paternalism accompanying male strength and power to be replaced by passive transfer of the same paternalistic power to women who do not have to realize thankfully or even gratefully believe what they have convinced men to do.

8. Feminists destroy the right to childhood by imposing adult sexuality and violence onto children so they do not learn positive life, sacrifice, virtue, love, humanity, peace, freedom and death without fear (the Catholic Mass Mantra).

9. Feminists have increased violence against women by ignoring the most common sites of such violence: lesbian households.

10. Feminists have become a genital cult, as party to the gay cult, which has de-natured "sex" into a selfish masturbatory culture deserving mockery, instead of love based sacredness in marriage offering unity and reproduction in concert with Nature and Nature's God.

11. Feminists have destroyed marriage as the psycho-social pheromone for humans ever since we escaped from biological pheromones which rule in nature for the rest of the animal kingdom confining animals to sexual activity only between opposite sexed mature members of the same species at time of likely reproduction.

12. Feminists have become promoters of "evil is good" authority-obedience of Adolf Eichmann well proven by Stanley Milgrim.

13. Feminists are SELFISH SEXISTS and all the words imply. 
14. To demand EQUALITY is a trap door. Think of the woman in the elevator who struck her NFL husband in a heated argument. An "I am a man too" equal proclamation. Of course, he decks her in a quick down and out and did not wail away like he would have if she were to be treated really as a "man". There is the other NFL guy in a bar and a pretty blond engaging in laughing then tense and hostile snarling, strikes him in the face with her closed fist--he decks her and all separate without his wailing away as if she were a man. Both gals proclaimed their womanhood after demonstrating their feminism. Both guys get penalized by the NFL who refuse to allow women to be men even when they act like men. Call it a violation of the Equal Misery Amendment.

The outrageous ad described above does and proves all this and it is not an isolated comment said privately like Donald Sterling's. It is an ad run daily for months. It is hateful, discriminatory, a public health hazard and against the law of equality. 